\title{
Analysis of Higher Education Readiness in Implementing Independent Curriculum - Independent Campus for Entrepreneurship Program
}

\author{
Yusnadi $^{1, *}$, Nani Barorah Nasution ${ }^{1}$, Husna Parluhutan Tambunan ${ }^{1}$ \\ ${ }^{1}$ State University of Medan \\ "Corresponding author. Email: yusnadi@ unimed.ac.id
}

\begin{abstract}
One of the very classic issue of the nation is the imbalance of employment compared to the number of job seekers. Entrepreneurship is an alternative solution to overcome this problem. Therefore, Higher Education has a role to embrace students to become new entrepreneurs who are competent in their fields so that they are able to produce and develop human resources who have high knowledge, confident and have an entrepreneurial skill. In the Independent Curriculum - Independent Campus, one of the programs that supports the improvement of entrepreneurial skills among students is Entrepreneurial Activities. This research is a policy research which aims to describe what the readiness of higher education is in organizing the Independent Curriculum - Independent Campus especially for entrepreneurial activities. The data collection technique in this study used a questionnaire about entrepreneurial activities at the Faculty of Education, State University of Medan, located in North Sumatra, Indonesia. This study involved 11 functionaries in the Faculty of Education and 61 lecturers. The results showed that most of the functionaries (36.4\%) stated that they were ready, and $27.3 \%$ were in a position not ready to implement entrepreneurship. While the readiness of lecturers in implementing entrepreneurship shows very high readiness, where 58 lecturers $(95.1 \%)$ stated that they were very ready and 3 lecturers $(3.3 .6 \%)$ stated that they were ready.
\end{abstract}

\section{Keywords: Entrepreneurship, Independent Curriculum - Independent Campus}

\section{BACKGROUND}

The topic of entrepreneurship has received considerable critical attention among scholars over the past decade [9]. Entrepreneurship has become a central issue in both developed and developing countries as an effort to improve the economic welfare of the nation [8]. Increasing entrepreneurship in a country will have an impact on improving people's welfare and alleviating poverty [1].

Entrepreneurship development is also the target of new developed countries, including Indonesia. However, based on the Global Entrepreneurship Index by Acs et al. in [8], Indonesia ranks 94 out of a total of 137 countries surveyed. Meanwhile, according to research from the IDN Research Institute in 2019, 69.1\% of millennials in Indonesia have an interest in entrepreneurship. Unfortunately, the entrepreneurial potential of the millennial generation has not been managed properly so far. Meanwhile, the prediction mentioned Indonesia is one of the developing countries whose economic development is estimated to dominate world economic development in 2025 [6]. This achievement is far from neighbouring countries such as Singapore, Brunei Darussalam, and Malaysia. To increase the number of entrepreneurs, the Indonesian government is pursuing several innovations including revitalizing the existing curriculum, encouraging the formation of good human resources, here education plays an important role in preparing Indonesian human resources to become quality human resources.

The Indonesian government must be able to create an education system capable of accommodating the formation of reliable human resources with high-level thinking skills that can be used in facing challenges in the world of work. The Ministry of Education and Culture of the Republic of Indonesia launched the Merdeka Learning Curriculum-Merdeka Campus which is a new term in the Indonesian education system which is intended to give students the freedom to choose fields according to their needs. One of the policies of 
Independent Curriculum - Independent Campus is to give students the right to take courses for three semesters outside the department, which are divided into one semester to take courses outside the study program and two semesters to carry out learning activities outside of college institutions [7]. Currently, learning activities outside the classroom are not optimal, therefore students had difficulty to seek new experiences by learning from the real work field. Moreover, in many campuses there is still an assumption that student exchange or practical work actually slows down student graduation, therefore it is important for campuses and faculties to formulate an appropriate planning curriculum so that the program taking three semesters outside the department can be achieved. One of the activities in the Independent Curriculum - Independent Campus is entrepreneurial activity. The objectives of the entrepreneurial activity program include: providing students who have an interest in entrepreneurship to develop their business earlier and be guided and to deal with unemployment problems that result in intellectual unemployment among scholars [7].

As previously mentioned, entrepreneurship is one of the targets that are trying to be developed in various countries. However, when compared to other countries, the number of entrepreneurs in Indonesia has not reached the target. So, it is important to provide opportunities for students to participate in entrepreneurial activities. Through entrepreneurial activities, it is hoped that students will be able to build an entrepreneurial spirit by creating creative ideas and innovations, then able to use and follow the increasingly rapid development of digital technology so that it will create new jobs and the number of unemployed decreases.

Usually, every policy change is accompanied by resistance. Likewise, the change in the policy of the Ministry of Education and Culture with the strategy of " Independent Curriculum - Independent Campus " must be balanced with the readiness of tertiary institutions to start a mindset change movement, and a change in the culture of an independent campus to manage learning. The new policy certainly brings consequences, both in relation to the supporting infrastructure and the mindset of its implementers. In terms of curriculum, Universities and Faculties need to adjust by harmonizing the current curriculum with Independent Curriculum - Independent Campus. The curriculum has been designed for lectures in study programs and has not accommodated entrepreneurial activities, so in this study it is necessary to map the readiness of each functionary and lecturer in the department to implement entrepreneurship programs within the Faculty of Education, State University of Medan.

\section{LITERATURE REVIEW}

\subsection{Independent Curriculum - Independent Campus}

The Independent Curriculum - Independent Campus is a policy of the Minister of Education and Culture, which aims to encourage students to master a variety of useful disciplines to enter the world of work. The important aspects in the main program of the Independent Curriculum - Independent Campus which includes: (1) Internships / Practical Work, (2) Projects in the Village, (3) Teaching in schools, (4) Student exchanges, (5) Research / research, (6) Entrepreneurial activities, (7) Entrepreneurial activities, and (8) Projects humanity [7]

The right to study three semesters outside the study program means that students are given the freedom to take subject outside the study program, three semesters in the form of one semester of opportunity to take courses outside the study program and two semesters to carry out learning activities outside of college [7]. Furthermore, various forms of learning activities outside of higher education, including doing internships / work practices in industry or other workplaces, carrying out community service projects in villages, teaching in educational units, participating in student exchanges, conducting research, conducting entrepreneurial activities, making independent studies / projects, and following humanitarian programs. All of these activities must be carried out with the guidance of the lecturers. An independent campus is expected to provide contextual field experiences that will improve student competence as a whole, be ready to work, or create new jobs.

Through the learning process in the Independent Curriculum - Independent Campus, it is hoped that student cantered learning can be achieved. Learning in the Independent Campus provides challenges and opportunities for the development of innovation, critical thinking skills, creativity, capacity, personality, and developing independence in seeking and finding knowledge through reality and field dynamics such as ability requirements, real problems, social interactions, collaboration, self-management, performance demands, targets and achievement.

\subsection{Entrepreneurship}

Entrepreneurship, which is often known as entrepreneurship, which is translated literally as an intermediary, is defined as an independent attitude and behavior that is able to combine elements of creativity, taste, and intention, and work or is able to combine elements of creativity, challenge, hard work, and satisfaction to achieve maximum achievement. Stoner James in [8] defines entrepreneurship as the ability to take the factors of production of labor, labor, and capital to use them to produce new goods or services. The entrepreneur is aware of opportunities that other business 
executives might not aware. The essence of entrepreneurship is to create added value in the market through the process of combining resources in new and different ways in order to compete. According to [10] added value can be created in the following ways:

a. New technology development (developing new technology)

b. Discovery of new knowledge (discovering new knowledge)

c. Improvement of existing products (goods and services)

d. Finding different ways to produce more goods and services with less resources (finding different)

\subsection{Readiness}

Readiness is' the willingness or state of being fully ready for something or ready to complete a task [4]. The greater the readiness of a party, the more likely it is to enter into negotiations or agree to negotiations if proposed. Readiness also encourages participation in prenegotiation exploration to enter new situations. Teachers are considered as the main factor determining educational development and innovation. Therefore, teachers 'readiness to learn based on interactive methods is a condition for developing students' creative abilities, learning depends on the strength and structure of motivation professional of teachers [3].

\section{METHOD}

This research is a policy research that focuses on policy implementation research, with the aim of developing recommendations needed by policy makers. This study aims to describe the readiness of higher education institutions in organizing Independent Curriculum - Independent Campus. Data collection techniques in this study using a questionnaire about entrepreneurial activities. This research was conducted at the Faculty of Education, State University of Medan, located in North Sumatra, Indonesia. This study involved 11 functionaries in the Faculty of Education and 61 lecturers.

\section{ANALYSIS RESULT}

\subsection{Readiness of Faculty of Education Functionaries of Medan State University}

The implementation of the Independent Curriculum Independent Campus requires the readiness of all elements in the faculty environment. The readiness and knowledge of functionaries in preparing and managing the process of implementing the independent learning curriculum for independent campus is important so that entrepreneurial activity programs in the independent learning curriculum can be carried out properly. The table below describes the readiness of the functionaries on implementing entrepreneurship activity. The indicators are the readiness of the lecture syllabus, the readiness of lecturers to collaborate in designing programs, readiness in assessments, readiness to work with entrepreneurship experts.

Table 1. The Readiness of Implementing Entrepreneurship Activity Among functionaries

\begin{tabular}{|c|l|c|c|}
\hline No. & Category & Frequency & Percentage \\
\hline 1. & Very Ready & 2 & 18.20 \\
\hline 2. & Ready & 4 & 36.40 \\
\hline 3. & Less Ready & 3 & 27.30 \\
\hline 4. & Not Ready & 2 & 18.20 \\
\hline & Total & $\mathbf{1 1}$ & $\mathbf{1 0 0}$ \\
\hline
\end{tabular}

Referring to Table 1, most of the respondents $(36.4 \%)$ stated that they were ready, and $27.3 \%$ were in a position not ready to implement entrepreneurship program. Only a small proportion $(18.2 \%)$ that were in the very ready and unprepared category.

\subsection{Readiness of Faculty of Education Functionaries of Medan State University}

The implementation of Independent Curriculum Independent Campus requires the readiness of all elements in the faculty environment, including lecturers. This curriculum change must also be accompanied by the rapid movement of the lecturers by starting a mindset change movement related to changes in campus culture with various programs in the independent campus learning curriculum. The following is an overview of the readiness of Faculty of Education lecturers for the implementation of entrepreneurial activities.

Table 2. The Readiness of Implementing Entrepreneurship Activity Among Lecturer

\begin{tabular}{|c|l|c|c|}
\hline No. & Category & Frequency & Percentage \\
\hline 1. & Very Ready & 58 & 95.1 \\
\hline 2. & Ready & 3 & 4.9 \\
\hline 3. & Less Ready & 0 & 0 \\
\hline 4. & Not Ready & 0 & 0 \\
\hline & Total & $\mathbf{6 1}$ & $\mathbf{1 0 0}$ \\
\hline
\end{tabular}

Based on the results of the analysis related to the readiness of lecturers in the implementation of entrepreneurship, it shows very high readiness, where 58 lecturers $(95.1 . \%)$ Stated that they were very ready and 3 lecturers $(3.3 .6 \%)$ stated that they were ready to carry out entrepreneurship programs. There are no lecturers who fall into the under and unprepared category.

\section{DISCUSSION AND SUGGESTION}

This study aims to determine the readiness of functionaries and lecturers in the Faculty of Education in 
implementing the Independent Curriculum Independent Campus, especially entrepreneurial activities. Data were collected using a questionnaire in the form of a questionnaire that was given online for later analysis.

The results of the analysis on the readiness of functionaries for entrepreneurial activities show that most of the respondents $(36.4 \%)$ stated that they were ready, and $27.3 \%$ were in a position less ready to implement entrepreneurship program. Independent Curriculum - Independent Campus was actually raised by the Ministry of Education and Culture in 2020, precisely when Nadiem Makariem was appointed minister of Education and Culture of the Republic of Indonesia. As an innovation, it is natural that the program cannot be completely understood and implemented. In the diffusion theory of innovation [5] which explains how a new idea and technology is spread in a culture. Diffusion as a process in which an innovation is communicated through various channels and a certain period of time in a social system. It is further explained that innovation is an idea, practice, or object that is considered new by individuals or other adoption units. The novelty of an idea, practice, or object will determine the reaction of certain individuals to the innovation. A person may already know the presence of innovation, but still not develop an attitude of support or resistance to the innovation [5].

Furthermore, the results of the analysis on the readiness of lecturers for Independent Curriculum Independent Campus for implementing entrepreneurship program, show that most of the respondent are in very ready category $(95.1 \%)$ and 3 lecturers $(3.3 .6 \%)$ stated that they were ready to implement entrepreneurship programs. This data shows that the readiness of lecturers in implementing the entrepreneurship program is very high.

The success in implementing the Independent Curriculum - Independent Campus begins with the readiness of various related elements including lecturers. In order to achieve the implementation of programs in the independent campus learning curriculum, it is determined by the readiness of lecturers to learn new information regarding the implementation mechanism of each program. Readiness is a person's willingness to do something, if it is related to the research results above, lecturers as educators are required to always be ready for various changes and continue to upgrade their competence and quality. This is one of the factors that causes lecturers to feel ready to run various programs in the independent learning campus learning curriculum. It is hoped that with a high level of readiness by the lecturers it will be the foundation so that the independent learning campus learning curriculum can study effectively and efficiently.

\section{CONCLUSION}

The conclusion in this study is that the readiness of lecturers for an independent curriculum and an independent campus shows very high, especially entrepreneurship programs. In achieving this readiness, supporting elements are needed, one of which is a lecturer. Therefore, the role of lecturers is very high in achieving the Independent Curriculum - Independent Campus.

\section{REFERENCES}

[1] Halvarsson, D., Korpi, M., \& Wennberg, K. Entrepreneurship and income inequality. Journal of Economic Behavior and Organization, 2018, 145, 275-293. https://doi.org/10.1016/j.jebo.2017.11.003

[2] Jones, J. J., and Walters, D. L. Human Resourse Management in Education. (Manajemen SDM dalam Pendidikan). Yogyakarta: Q-Media. 2009.

[3] Kariyev, A., Turganbayeva, B., Slambekova, T., Zheldybayeva, B., \& Kabdualiyeva, A. Model of Formation of Teacher's Readiness to Learning on the Base of Interactive Methods as the Conditions of Creation of Students Abilities. Procedia - Social and Behavioral Sciences, 190 (November 2014), 2015, 353-357.

https://doi.org/10.1016/j.sbspro.2015.05.010

[4] McIntosh, C. Cambridge Advanced Learner's Dictionary (4th ed.) 2015.

[5] Rogers, E. M. Diffusion of Innovation. The Free Press. 1983.

[6] Rokhman, F., Hum, M., Syaifudin, A., \& Yuliati. Character Education for Golden Generation 2045 (National Character Building for Indonesian Golden Years). Procedia - Social and Behavioral Sciences, 141, $2015.21161-1165$ https://doi.org/10.1016/j.sbspro.2014.05.197

[7] Tohir, M. Buku Panduan Merdeka Belajar - Kampus Merdeka.

2020.

https://doi.org/10.31219/osf.io/ujmte

[8] Wardana, L. W., Narmaditya, B. S., Wibowo, A., Mahendra, A. M., Wibowo, N. A., Harwida, G., \& Rohman, A. N. The impact of entrepreneurship education and students' entrepreneurial mindset: the mediating role of attitude and self-efficacy. Heliyon, 6(9),

2020.

\section{https://doi.org/10.1016/j.heliyon.2020.e04922}

[9] Wichstrøm, L., \& von Soest, T. Reciprocal relations between body satisfaction and self-esteem: A large 
13-year prospective study of adolescents. Journal of Adolescence, 47(7491), 2016, 16-27. https://doi.org/10.1016/j.adolescence.2015.12.003.

[10] Zimerer, Thomas W. and Scarborough, Norman, M. Essentials Entrepreneurship and Small Business Management. 2nd Edition. New Jersey: Prentice Hall, Inc. 1998. 